University of Nebraska - Lincoln

DigitalCommons@University of Nebraska - Lincoln

To Improve the Academy

Professional and Organizational Development Network in Higher Education

1996

Professors as Clients for Instructional Development

Ronald A. Smith

George L. Geis

Follow this and additional works at: https://digitalcommons.unl.edu/podimproveacad

Part of the Higher Education Administration Commons

Smith, Ronald A. and Geis, George L., "Professors as Clients for Instructional Development" (1996). To Improve the Academy. 367.

https://digitalcommons.unl.edu/podimproveacad/367

This Article is brought to you for free and open access by the Professional and Organizational Development Network in Higher Education at DigitalCommons@University of Nebraska - Lincoln. It has been accepted for inclusion in To Improve the Academy by an authorized administrator of DigitalCommons@University of Nebraska - Lincoln. 
Smith, R.A. \& Geis, G.L. (1996). Professors as clients for instructional development. In L. Richlin (Ed.), To Improve the Academy, Vol. 15 (pp. 129-153). Stillwater, OK: New Forums Press and the Professional and Organizational Development Network in Higher Education. Key words: Faculty Development, Faculty Development Role, Instructional Development, Needs Assessment

\section{Professors as Clients for Instructional Development}

\section{Ronald A. Smith}

Concordia University

\section{George L. Geis}

Ontario Institute for Studies in Education

Although there is a large amount of activity and a sizeable literature in the area of instructional development, there has been relatively little research on faculty members, the clientele for improvement efforts. This paper highlights some characteristics of professors that are relevant to improvement activities. Professors are interested in, value, and work on their teaching; they think they teach rather well. However, they demonstrate a lack of sophistication in talking about teaching and the development of instruction. They focus primarily upon content rather than design or methodology. Teachers' views of what should be done to enhance instruction are discussed and contrasted with those of faculty developers. One conclusion is that faculty developers and faculty members may have very different views on how to go about improving instruction.

The relationship of professional expert to client has undergone profound changes in recent years. In the past, the picture of the professional was that of a know-it-all and the client was a know-nothing. When going to visit a physician, one often regressed to almost a 
child-like state of innocence and dependency. The movement today, dramatically seen in medicine, is toward at least equality of the partners in the helping relationship. Better still, the professional seeks a deeper understanding of the concerns and perceptions of the client early on in the relationship.

"Know thy client" has long been a first commandment for change agents. The movement among the professions toward a deeper understanding of, and greater sensitivity to, the client has probably been fuelled by a number of societal trends such as greater accountability in the professions and recognition of and respect for diversity in client populations (Sullivan, 1995). It also springs from a recognition that, to be effective, change strategies must include acquiring and using a deeper understanding of the client, together with their voluntary participation. An example of this trend in education has been the evolution of the role of the evaluator: from that of an outside and alien expert to one closer to that of an anthropologist seeking to know about (and possibly help) members of other cultures (Guba \& Lincoln, 1989).

An example of a client-expert relationship undergoing such changes is that of professor and faculty developer. Attempts at improving postsecondary teaching through faculty development have been visible for the past three decades. A comparison of reports of faculty development in the 1960s (Alexander \& Yelon, 1972; Eble, 1971; Many, Ellis \& Abrams, 1969) with those in the 1970s (Centra, 1976; Donald \& Shore, 1976; Gaff ,1975) and 1980s and 1990s (Donald, 1986; Eble \& McKeachie, 1985; Erickson, 1992; Konrad, 1983) reveals that these efforts have increased in number, variety and complexity. It is important to note the demographic changes in the client population. Whereas the 1960 s saw a sizeable influx of new professors on most campuses, the 1980s presents clients who have been in place for 20 years and are increasingly tenured staff. The likelihood is that a flow of new staff to the professoriate will occur in a few years. At the time the emphasis in development might shift from continuing, in-service education back to orientation of new staff.

Relevant professional organizations now exist and hold annual conferences; for example, the Professional and Organizational Development Network in Higher Education (POD), the Society for Teaching 
and Learning in Higher Education (STLHE), the Staff and educational Development Association (SEDA), the International Alliance of Teacher Scholars (IATS), the Higher Education Research and Development Society of Australasia (HERDSA), and the American Educational Research Association (AERA) Special Interest Group in Faculty Evaluation and Development. In addition, there are journals such as the Journal of Staff, Professional and Organizational Development and the Journal on Excellence in College Teaching.

Yet what we really know about one major client population, post secondary teachers, is minimal. We use the terms professor, faculty member, and teacher synonymously throughout the paper. We, of course, recognize that institutions make important distinctions among them, but those discriminations vary from campus to campus. As we suggest later, the particular definition has bearing on the faculty developer's role. In this paper we are interested in the teaching aspects of members of post-secondary faculties. A few demographic studies are available (Carnegie, 1989; Chronicle, 1990); we have some information on stress and aging in the professoriate (e.g., Bowen \& Schuster, 1986; Gmelch et al., 1984; Seldin, 1987). But prescriptions for teaching and teaching improvement far outweigh our knowledge about professors as teachers.

It appears that the investment in change efforts has been infinitely larger than the investment in research on the college and university teacher. This in part may be a factor of the lack of substantial evidence on the impact of faculty development activities (Centra, 1976; Smith, 1984; University of Manitoba, 1980; Weimer \& Lenze, 1991). This paper presents our observations, drawn from the research literature and our experiences, about college and university teachers, in particular their perceptions of their teaching role. We conclude with some implications for faculty developers.

\section{Faculty and Instructional Development}

The term faculty development covers a number of different approaches. Gaff (1975) and Bergquist and Phillips (1977) originally distinguished among development at three levels: personal, instructional and organizational. These categories have not changed signifi- 
cantly over 20 years. The raison d'être of these activities is to produce better research, better teaching, smoother, more effective management, and higher morale among faculty members. In this paper we focus upon the professor's role in instruction and consequently the title includes the term instructional development. However, we also use the term faculty development in the paper to emphasize the wholeness of the enterprise and not the separateness of the instructional component.

\section{Professors as Teachers}

Faculty are interested in teaching. Although perceptions vary widely from institution to institution, major studies conducted over the past 25 years report that teaching is perceived of as important by faculty (Blackburn et al., 1980; Carnegie, 1989); and it is a "major source of satisfaction" (Wilson \& Gaff, 1971; Chronicle, 1990). It is often seen as the professors' major activity (Bayer, 1973), although some critics have criticized the relatively few hours of classroom contact time reported for most teachers (Smith, 1991). In fact, the majority of faculty would like to reverse the push towards research and restore the balance by increasing the emphasis on undergraduate teaching (Gray, Froh, \& Diamond, 1992).

Faculty members think that they are doing a good job teaching (Feldman, 1989). Ninety percent of the faculty judge themselves to be above average or superior teachers, according to Blackburn, et al.(1980). However, they often note that their colleagues are not quite as expert as they are. Blackburn's findings confirm the results obtained by Cross (1977) in her Nebraska study. Cross notes:

[W] hat may as well be starkly labelled smug self-satisfaction. An amazing $94 \%$ rate themselves as above-average teachers, and $68 \%$ rank themselves in the top quarter on teaching performance. Though they are not quite as pleased with their colleagues as with themselves, $60 \%$ are satisfied with the quality of undergraduate instruction in their department; only $5 \%$ are dissatisfied most of the time. (p.10)

Despite what appears to be almost bovine contentment with their teaching, faculty members seem concerned with improving it. How faculty members view their role as teacher is likely to influence what 
they undertake to improve their teaching (Geis \& Smith, 1977/78; Smith, 1983). Professors who view themselves as experts or formal authorities, to use Mann's terms (1970), or as teaching "principles and facts," to use Axelrod's category (1973), will be much more likely to focus their teaching preparation and improvement efforts on the content of the course, its currentness, completeness and organization compared, say, with teachers who view their role as facilitators or think of teaching students as persons. Underlying each of these roles is a set of implicit beliefs about the way teachers should be. The differences among faculty in the emphasis, satisfaction, and training for these roles influence to which areas they attend when trying to analyse, evaluate and improve their teaching.

\section{Professors as Naive Teachers}

The research suggests that faculty members hold a rather limited view of the nature of teaching. Cross (1990) has observed that although teaching can be intellectually challenging, it is generally practised at a primitive level. Faculty do not deal with the instructional process with the degree of sophistication that they demonstrate when talking about content. Almost 20 years ago Freedman et al. (1979) summarized one theme from their interviews with over 700 faculty this way:

[Their] discussions of educational programs or reforms usually proceed as if education had no discipline, no organized or systematic body of theory and knowledge and no need for such a discipline. In short, faculty approach teaching and education as would any intelligent adult chosen at random - on the basis of some opinion and reading and some knowledge based on experience. (p.8)

More recently, Cross (1990) made the same point using an analogy to farming, stressing the lack of knowledge and motivation to deal with the evident ineffectiveness of teaching:

We don't really know why some students thrive and others don't. We don't often observe whether the seeds we plant take root. We can't detect wilt. And even when we see the beginning signs of boredom or disengagement, we don't take immediate steps to treat it because we assume it's the nature of the plant to wilt-or, more often, perhaps, because we don't know how to treat wilt or we don't have time. (p. 5) 
Popular books on teaching written by professors in fields other than education reinforce this perception. Typically, they recount stories of great professors who are eccentric and idiosyncratic in their approach to teaching and who, it is claimed (without any data accompanying the claim) are effective teachers. The recurrent (and, to some, reassuring) themes in such books are that: a) subject matter expertise is the key to the success of these teachers, and b) other than this, the techniques displayed are unique and have to do with inborn personality traits rather than acquirable skills and knowledge. These ideas persist as myths, particularly around student evaluation of teaching, which inform practice, in spite of the research evidence to the contrary (Cashin, 1988, 1995; Cohen, 1990).

All of this is depressing, but not surprising. Postsecondary teachers have had little preparation for their teaching role. Almost none have had courses in education, much less degrees in the field. Teaching assistants tend to be treated as a pool of cheap academic labor rather than apprenticeships learning teaching skills, although this has recently started to change (Richlin, 1995). Advanced degrees in teaching, such as the Doctor of Arts, have not proven popular substitutes for the Ph.D. (Glazer, 1993).

\section{Professors as Teachers and Researchers}

As one might predict, given their tendency to describe teaching in terms of content and their lack of educational models or theories, faculty members define excellence in teaching in terms of scholarship and knowing the subject matter. They direct their teaching improvement efforts toward keeping abreast of new developments and carrying out research or other scholarly activities (Boyer, 1990; Rice, 1984). Despite the research showing no connection between excellence in research and teaching (Feldman, 1987; Task Force on Resource Allocation, 1994; Terenzini \& Pascarella, 1994), the perceptions of a strong connection have persisted. In 1971, Wilson and Gaff reported the majority of faculty they sampled indicated that "involvement in research makes for more exciting teaching" and that "teachers involved in research are likely to keep up in their fields" (p. 40). Wilkerson (1977) concluded that most faculty "viewed effective 
teaching as an outgrowth of research and publication activities suggesting that thorough knowledge of the subject is the sole prerequisite of good teaching" (p. 190). Indeed the assumption that research activity is the prime element in producing good teaching seems problematic. For one thing, most professors do not continue to be researchers after completing their graduate work. All of these would be condemned to second rate teaching status according to the assumption. In addition, large numbers of professors (over $50 \%$ at research and doctorate granting universities) report that the pressure to publish in fact reduces the quality of teaching (Carnegie, 1989).

The relationship between teaching and research is further complicated by the blurring of definitional boundaries between research and scholarship. Boyer (1990) enlarges the concept of scholarship to include discovery, integration, application, and teaching. Similarly, the Smith Report (1991) calls for an enlargement of the concept of scholarship beyond the narrow definition of publication of research articles. Smith would include within scholarship study taken in preparation for teaching and action research about teaching. Stretching the definition clearly would have impact on the reward and status systems at colleges and universities and likely have implications for the importance with which teaching is viewed. The effort to move beyond "pedagogical solitude" towards treating teaching as "community property" (Shulman, 1993b) and the "Peer Review of Teaching" project (AAHE, 1995) are examples of work in this direction.

The amalgam of teaching and research roles may be attractive because it is cost-effective. Thus, the same activities can contribute to two different professional roles. But it also can be seen as the natural flowing together of scholarship and instruction. If one holds the latter view, a coherent continuous set of activities can be developed and justified. Given the multiple pressures to publish, stay current with the literature, serve on committees, garner grant money and teach students, it appears that such a strategy is not to be criticized as a matter of keeping two sets of books; it is an efficient strategy for increasing productivity and for survival.

It does an injustice to individuals within any profession to represent them only as a stereotype. Certainly the variability among professors is as interesting as any generalization about them. Such 
differences arise not only because of individual variables but also because of the different environments in which they work: community colleges, liberal arts colleges, research and teaching universities, graduate and undergraduate programs, and various disciplines (Marincovitch, 1996). Nevertheless, the preceding discussion has provided some insights about the professor-as-teacher, and therefore the professor as client.

The picture that emerges of professors is that of content experts interested in teaching, believing that they are doing a good job, and engaging in teaching improvement efforts that seem appropriate, all within particular and personals view of what teaching is about and what the role of the teacher is. The way one frames the problem determines the solutions one tries (Schön, 1983; Smith, 1995). Many professors view teaching as the transmission of knowledge and as a means of developing in the learner a way of structuring or thinking about a particular domain of knowledge. Professors recognize the key role that teaching plays in their lives, but they are essentially untrained for it and rely upon (or even extol the efficacy of) their own intuition and experience. They recognize the demands of and possible conflict with another role, that of scholar and researcher. In the face of potential conflict of roles, many seem to have blended the two, emphasizing the contribution of their research to teaching (and, more recently, trying to point out how teaching can contribute to research). Shulman (1996) makes the case for the scholarship of teaching as integrating the other scholarships, and offers the course portfolio as a vehicle for beginning to explore the "dissection and transformation of knowledge."

This is the picture that we see emerging from discussions and descriptions of the professor. There is, of course, another actor in faculty development consultation to whom we will now turn our attention: the faculty developer.

\section{The Faculty/ Faculty Developer Connection}

People who offer help to others generally begin with the assumption that there is or may be a problem or need which requires their assistance. What is the problem that faculty developers appear to be addressing? 
As we indicated earlier, from the faculty members' point of view clearly the problem is not poor teaching. But administrators proclaim the need for improvements in instruction (Cochran, 1989; Nelson, 1980). Faculty developers may imply the same perceived need as they press teachers to accept their assistance. Popular books declare that teaching is in a sorry state in North America (Bloom, 1987; Bowsher, 1989; Sykes, 1988; Wilshire, 1989). Students periodically complain loudly about the quality of teaching. The Smith Report (1991) calls for "nothing less than a total recommitment to teaching" (p. 63). Teaching should be evaluated better; good teaching should be rewarded, and more funds should be made available for faculty development. But most postsecondary teachers already seem to be committed to good teaching. The faculty developer is faced with a paradox, one not infrequently encountered when dealing with clients: the client does not perceive the need for assistance.

The faculty developer's difficulties are exacerbated by lack of real support by others, including the very people who are complaining about the quality of education. When one looks beyond the rhetoric for signs that others, such as administrators, assign high priority to teaching improvement (North, 1995), one sees that they have been hesitant to commit sizeable and continuing resources to faculty development. In the last decade faculty/instructional improvement centers have seen severe budget cuts or have been abolished. Even traditional development activities such as sabbatical leaves have been curbed in many institutions. Those who perceive that there is a problem with teaching fail to assign urgency and high priority through their own actions. It may be that the window of opportunity for teaching improvement that we witnessed during the late 1980 s, has closed to be replaced with new pressures on faculty to be productive, to be involved in service, and to practice "civic professionalism" (Sullivan, 1995).

And, indeed, what precisely is the problem that faculty developers are being asked to address? A look at improvement efforts that have been undertaken and suggestions for further activities do not provide clarification. Do the data from teaching evaluations suggest there is a dire need for improvement? Not really. Professors generally rate themselves highly as teachers, and so do students (Centra, 1993; Feldman, 1989). What of those professors who are not rated as highly? 
Is it that they professors know how to teach well but do not do so because of say, incompatible heavy research demands? Or is it that they are demotivated because good teaching receives little recognition? Or is it that professors, having little formal training or systematic guidance, simply do not know how to teach well? Each of these questions, or ways of setting the problem, suggest quite different solutions to the teaching problem (Smith, 1995). To put it another way, each suggests a different answer to the question: Whose problem is it?

Administrators, students, and, to some extent, faculty developers place the responsibility for improvements in instruction squarely on the teacher. Cross and Angelo (1988) state as the first assumption underlying classroom research: "The quality of student learning is directly - although not exclusively - related to the quality of classroom teaching. Therefore the first and most promising way to improve learning is to improve teaching"(p. 1).

To the extent that poor student performance is cited as a continuing problem, faculty members are likely to admit that learning could be improved; but, for them, improvement would depend, in good part, upon changes at the organizational level. For example, poor outcomes, the performance of students, may result from deteriorating admission standards. The results of research reported elsewhere (Smith 1984, 1985 ) suggest that faculty members only infrequently attribute student failure or even classroom difficulties to their own lack of teaching skills. In fact, they often attribute causes in such ways as to preclude solution by the teacher (Smith, 1984). That is, they often define the problem as beyond their control and the solution as not their responsibility. For example, diversity in student background, degree of preparation, and interests present problems which are seen as traceable to the Admissions Office. Not many professors pretest students on the first day of class and adjust the instruction accordingly, although some report that they pick up information during the first few classes, through questioning and discussions, which does affect the forming of the course. The point is that there are serious differences in the perceptions about what the problems are, what the causal factors are and who is responsible for the solution (Geis, 1979; Smith, 1995).

For a number of reasons the professor's perceptions are likely to prevail. To a large extent the classroom is sacrosanct. The evaluation 
of the outcomes of teaching (such as regular monitoring of examination scores student response questionnaires) are seen as intrusive and, perhaps infringements on academic freedom. Teachers have their courses, classrooms, and students. It would seem to follow that they should be responsible for the effectiveness of the teaching that occurs. But the teacher often argues that the necessary resources and motivating conditions (for both student and teacher) for doing a proper job are not available, thereby moving the locus of control and the responsibility for action to the larger organization. This relieves the professor not only of the burden of changing, but also of any sense of accountability for failures. The next level of the problem analysis we are pursuing poses the question: What should (or can) be done?

The vast majority of professors indicate that they are working on their teaching each year. But this is not necessarily because they perceive there is a problem with their teaching. Rather, one might think of it as analogous to an artist continuing to paint the same general scene in successive paintings. Most of these efforts are in the context of the content model of pedagogy, in which excellence is defined as the best content (Astin, 1985). This is in dramatic contrast to the individualized model where excellence is defined in terms of the development of human talent (Astin, 1985; Chickering, 1981). In this latter model methods are important and involving students in learning is paramount (Chickering \& Gamson, 1991; Mortimer et al., 1984).

There is considerable difference of opinion between developers and professors about what needs to be done to improve teaching and learning, and these differences haven't changed much over the last 20 years. In a study based on more than 500 interviews on 20 campuses, Nelson (1980) reported on what faculty members saw as the major faculty development needs at their institutions. Their concerns were in fairly traditional areas, such as financial support for research, travel, study, and sabbaticals. Also mentioned relatively frequently were group projects such as faculty seminars, workshop, colloquia and interdisciplinary and core curriculum development. In contrast improvement in teaching was a relatively low priority among faculty for their own development. While faculty members perceive themselves working on their teaching, they do not seem to view it as an improvement per se. 
Organizational and administrative changes were at the top of the faculty's "needs list" in Cross's (1977) study at the University of Nebraska.

The overwhelming first choice is an "unambiguous commitment to recognize good teaching at the same level as good research, with salary and promotion." Eight-one percent consider this change in the reward system extremely or very important to better teaching. (p. 11)

Over 57 percent picked other traditional favorites such as smaller classes, reduced teaching loads, better facilities and release time. On the other hand, Cross (1977) also reports that:

At the low end of the scale, considered very important by only 24 to 32 percent of the faculty, were such things as on-campus seminars on teaching, required training for new faculty members, and the publication of a newsletter about teaching innovations. (p. 13)

Fifteen years later a major study of 23,000 faculty chairs, deans and administrators at research universities concluded that the balance between teaching and research in the reward system is inappropriate and needs to be modified, elevating the position of teaching (Gray, Froh \& Diamond, 1992; Shulman, 1993a). Faculty developers also agree (Wright \& O’Neill, 1995).

There are some encouraging signs that administrators are aware of the key role they play in supporting good teaching. For example, the American Association for Higher Education (AAHE), an organization composed primarily of administrators, has chosen teaching as the theme for three of its annual conferences: "Taking Teaching Seriously" (1987), "The Highest Calling: Teaching To Rebuild the Nation" (1988), and "Stand and Deliver: Succeeding Against the Odds" (1989). In addition, AAHE has offered conference sessions on teaching portfolios, and has established a Forum on Exemplary Teaching in which more than 500 faculty members come together to discuss their teaching, an uncommon activity on their individual campuses. AAHE also has sponsored four major national conferences on Faculty Roles and Rewards, and played a leadership in the Peer Review of Teaching project (AAHE, 1995).

In summary, faculty are concerned with and interested in their teaching and find it quite satisfying; they continue to work at it in their 
own way. Many of the activities they engage in, which they see as enhancing their teaching, may as well be seen as the natural ones a scholar engages in, teacher or not. They still seem to "feel that they already know how to be effective teachers given the necessary time, equipment, support and so on" (Cross, 1977, p.13). Any increase in their knowledge or skill related to style, method and the nature of the student emerges from their experience, trial and error and reflection (Martin, 1981; Noonan, 1980) or through examination of their own classroom practices (Angelo \& Cross, 1993).

\section{Implications for Faculty Development}

We have implied that the views and approaches of at least some faculty developers may be in sharp contrast to their client-professors. The clients may have quite different perceptions of the nature of teaching, the problems associated with teaching, the role of the teacher, and the responsibility for change. Developers may start with the assumption that instruction is poor enough to need drastic fixing. They may focus exclusively upon individual professors, ignoring organizational context and influences. They may see initial contact with the professor as an opportunity for re-studying goals and structures. They may offer opportunities to enhance skills and knowledge in areas in which their clients either do not see themselves as deficient or which they do not see as relevant. We do not wish to judge the perception of either of the parties as "correct" or "incorrect." We simply wish to point out that there is often a sizeable gap between client and developer at the outset of the process of faculty development. This gap can lead to strategies which, however worthy, may appear inappropriate or even unfathomable to one of the partners. The developer, for example, may address deeper issues such as the relation of course to curriculum, or the need for valid evaluation instruments, before the client is aware of and can appreciate them. The professor may simply want tips on improving lectures and the developer may be trying to reduce the amount of lecturing and increase participation in the classroom. On the other hand the developer may provide only handy teaching tips to a professor who is, in fact, struggling with organizing the knowledge base of the course. 
Most of the models and techniques for instructional development and delivery have arisen in environments such as corporate training in which each element of the instructional package is contributed to by different experts: instructional designer, media expert, evaluator, instructor, or subject matter expert. Some school teachers and many trainers are involved solely in the delivery of instruction. In contrast, in higher education different instructional roles are combined in a single professor. The professor is a one-person band. Consequently the principles derived from the instructional design literature and research may not be directly or at least easily applied to college and university settings (Geis, 1996).

The faculty developer with a background in instructional design (Dick \& Carey, 1990) may drive professors into areas about which they have little knowledge and little understanding of their relevance to teaching. Faculty developers with other backgrounds such as counseling may fail to grasp the importance of epistemological issues which the professor sees as paramount.

It is important to recognize that both the client and the developer bring to their interaction not only the perceptions which we have discussed above, but also a necessarily limited set of competencies and skills. To the extent that the developer, with all good intentions, directs attention to areas of deficit, and consequently may induce insecurity in the professor, the consultative process is likely to be derailed. Most developers have experienced the obscure game-playing that results from such confrontations.

\section{Using What We Know About Faculty}

Obviously, getting to know the individual faculty member is a prerequisite to effective change and improvement. We have already noted that, more broadly, one should recognize that there are likely to be differences between various sub-sets of college and university teachers.

The university research professor tends to teach graduate seminars often in a specialized area of research. The community college instructor is likely to be a full-time teacher, on some campuses constrained not to engage in research, teaching a heterogeneous group of students, 
including numerous part-timers, and teaching a variety of courses perhaps none of which is concerned with the instructor's own special interests or knowledge. The teacher in a university professional school presents still another picture, often heavily committed to teaching with a target audience of practitioners, having to interact regularly with field sites and yet pressured to carry out research. Each of these types of professors presents quite different challenges to the faculty developer.

There are differences in clients from different disciplines (Marincovich, 1996). Consulting with a professor of accounting might well require a different approach than consulting with a professor of literature. Some subject matters and programs are highly structured as in the physical sciences. For a professor in one of these areas, references early in the consultation process to testable outcomes and prerequisites for later courses will make sense. However, initially focusing on such matters when consulting with professors of Sociology or English Literature may be confusing and distracting.

While an appreciation of such differences among clients is important, the general approach of the consultant to any client is equally so. Paradoxically, one of the reasons for the gap between developer and professor appears to be that faculty developers have dealt with their clients in the very ways they warn professors not to deal with their students: as content experts transmitting knowledge and providing elaborate answers to questions that are not being asked, rather than acting as facilitators for individualized learning. Elsewhere (Geis \& Smith, 1989; Smith, 1985) we have suggested the application of adult learning theories as a strategy for bridging the gap between professor and developer. In doing so we are elaborating what has been proposed and demonstrated by a number of faculty developer-authors (Bergquist \& Phillips, 1975, 1977, 1981; Angelo \& Cross, 1993; Lindquist, 1978; Konrad, 1985).

Faculty developers should take seriously the professor's emphasis on organizational variables. Despite their seeming isolation, the image of professors not only in an ivory tower but also within a locked room in that tower, obviously needs examination. Professors are increasingly aware of their interaction with the rest of the organization. Unionization and the professionalization of campus administration 
have produced a picture of the professorship as a job embedded in an organization that, for better or worse, increasingly resembles a business. If faculty developers consider the campus as an organization, they might follow the lead of progressive Human Resource Development units in business and industry. They increasingly see their role as more than adjusting trainees to the environment and take a more proactive stance in attempting to influence organizational decisions. Faculty developers should not be placed in the position of offering remedial treatments to victims of hostile environments. They might inform professors about critical organizational variables (and opportunities) and the expectations of others, particularly administrators, in the organization. And faculty developers could work with administrators as well as faculty to adjust expectations. Boyer (1990) proposes "creativity contracts" which would recognize the diversity of faculty members' talents and interests as well as the changing seasons of academic careers. He suggests that expectations and evaluations not only be broadened but also be individualized and continuous. Wergin (1994) suggests that we need to develop ways to recognize and reward the work of departments as collaborative groups.

A problem facing the developer is the client's perception of his/ her own expertise. Professors usually become expert in recognizing their degree of expertise in their discipline area. But it is our observation, supported by self-reports and questionnaire data, that they are less accurate in determining their competence as teachers and instructional planners. This might be expected given the paucity of their training in this area. The developer confronts clients who are highly expert in one professional role but may be at the novice level in another-while perceiving themselves as competent in both.

Their perception of the increased work resulting from the addition of new and complex tasks, including technology, to their teaching role should be approached cautiously and sensitively. The professor may see the developer as somewhat too eager to help and to use his/her expertise. As a reluctant client the professor may sense that $\mathrm{s} / \mathrm{he}$ deprives the developer of this opportunity and see the developer as pressing for certain actions which will produce the occasion for the display of those skills. We lack sufficient data about how faculty developers see themselves and how professors view them. A more 
complete picture certainly would be helpful in carrying out productive interactions.

As noted earlier the professor is first of all a scholar, devoted, one hopes, to an intellectual life. The professors' identification, as we have repeatedly noted, is with their discipline and its domain of knowledge. This should be the context in which the consultative process takes place. Taylor (1993) calls for a scholarship-based approach to faculty development. "When the primary emphasis in improving teaching is not imbedded in ... scholarship, instructional development efforts will lose credibility" (p.67). "An effective strategy should draw on and respect the primary resource of professors - their accumulated knowledge in a discipline - thereby establishing common ground for thinking and talking about the teaching and learning process" (pp. 68-69). This is similar to the point made by Shulman (1996) about integrating the scholarships.

As we noted at the outset the traditional model of helping has been changing dramatically; it probably never was the best one for the faculty developer to adopt. The client is increasingly becoming a partner in the change process not a recipient of it. Any model of change requires knowledge of the client; but a non-hierarchical, cooperative model especially demands such knowledge.

Faculty development programs should not only be pedagogically sound but also intellectually interesting (Konrad, 1985). The faculty developer is faced with a delicate problem: dealing with a group of people who are committed to an intellectual life and who are often experts in a particular field of study. Yet the developer may assume (with justification) that most clients are poorly informed about many educational matters. To engage such a learner, that is, to elicit a "need to know," requires tact and sensitivity. Furthermore, the actual learning experiences must be of a high order of challenge in order to interest the learners and to avoid insulting their intelligence.

We should recognize that we are not dealing with naive teachers; we should use their experiences as bridges to new learning. We should treat them as adult learners and work to be facilitators of their learning rather than their teachers (Geis \& Smith, 1989). Their need to know grows out of their concern for solving the problems they see; and their 
previous knowledge and experience will shape their choices of the knowledge or skills they seek to acquire.

It is interesting to speculate that "teaching" in postsecondary classrooms is usually seen as an "ill structured" problem (Newell \& Simon, 1972) —one in which the task emerges and is elaborated upon during the task performance. In contrast "instruction", for example, creating self-instructional packages for distance learning, may more closely resemble a "well-structured" problem, amenable to more pre-implementation activities (e.g., detailed planning; designing) and guided by a set of heuristics. To the extent that the faculty members perceive the environment as presenting problems of the first type they will not be en rapport with a facilitator who perceives the situation in the second way.

Houle (1980) describes three modes of learning which are part of the continuing education of professionals: inquiry, instruction, and performance. Since most faculty members have had no formal "instruction" in methods of teaching they must either learn through inquiry, or on-the-job, usually with very little supervision and almost no input from colleagues. Faculty, indeed may learn to teach by teaching but as Houle points out "experience is a hard teacher because it gives the test first, the lesson afterwards" (p. 209).

Schön $(1983,1987)$ has further developed the idea of learning by doing through the examination of the work of competent professionals. He has explored the knowledge exhibited in the actions of experts, implicit or tacit knowledge that is acquired through reflection-in-action. It is evident that professional practice is more than the application of theories to solve problems - more than technical rationality. In complex and ambiguous situations, professionals must first "frame" or name the problematic situation; then they must "make moves" or act to solve the problem they have named; finally they must listen to feedback from the situation to determine if they need to invent new action strategies or reframe the situation. Applications of Schön's' model can be found in teacher education (Grimmett \& Erickson, 1988) and continuing professional education (Cervero, 1988).

Schön's concept of the reflective practitioner together with the idea of "theories-in-action" (Argyris \& Schön, 1974) have been applied in faculty development work (Smith, 1983; Smith \& Schwartz, 
1988, 1990). Faculty are asked to examine their own behaviour in teaching situations that they describe as difficult, ones in which they have not been as successful as they wanted to be, or ones in which they did not achieve their intentions. Such cases are concrete, specific and personal, ones in which faculty members have the most to learn and the greatest need to learn. Consequently they are willing to examine a slowed down version of their usually automatic behaviour to determine what it was that they were doing which might have been counterproductive. They examine their own reasoning and actions in real case studies drawn from their own practice; they identify the ways in which their thinking and actions limited their effectiveness; they search for how they limited the generation of the valid information necessary for effective problem solving. And they go on to learn new behaviours which are more effective. This process of "re-education," though often effective, is not easy or quick (Putnam, 1990).

A somewhat similar strategy has been proposed by Angelo and Cross (1993). It respects the client and recognizes his/her knowledge assisting the professor's evolution as a classroom researcher who, as scholar and researcher, focuses on the important phenomenon of teaching and learning in the classroom. Far from presenting the traditional hierarchical expert-client relationship, it empowers the client by handing over to an already skillful scholar pedagogical problems for systematic investigation.

Faculty development programs need to reflect the richness and diversity of professors' perceptions and backgrounds, and to respond to their high degree of sophistication as professionals (although not always as teachers). As well, they need to demonstrate our best knowledge about the change process and professional practice and competence by showing better understanding of the client.

\section{References}

AAHE. (1995). From idea to prototype: The peer review of teaching (A project workbook). Washington, DC: AAHE.

Alexander, L.T \& Yelon, S.L. (1972). Instructional development agencies in higher education. East Lansing, MI: Continuing Education Service, Michigan State University. 
Angelo, T. A., \& Cross, K. P. (1993). Classroom assessment techniques: A handbook for college teachers. (2nd ed.). San Francisco: Jossey-Bass.

Argyris, C. \& Schön, D.A. (1974). Theory in practice: Increasing professional effectiveness. San Francisco: Jossey -Bass.

Astin, A. (1985). Achieving educational excellence: $A$ critical assessment of priorities and practices in higher education. San Francisco: Jossey-Bass.

Axelrod, J. (1973). The university teacher as artist. San Francisco: Jossey-Bass.

Bayer, A.E. (1973). Teaching faculty in academe: 1972-73. Washington, DC: American Council on Education.

Bergquist W.H. \& Phillips, S.R. (1975). A handbook for faculty development (Vol. 1). Washington, DC: Council for the Advancement of Small Colleges.

Bergquist W.H. \& Phillips, S.R. (1977). A handbook for faculty development (Vol. 2). Washington, DC: Council for the Advancement of Small Colleges.

Bergquist W,H. \& Phillips, S.R. (1981). A handbook for faculty development (Vol. 3). Washington, DC: Council of Independent Colleges.

Blackburn, R.T., Boberg, Q., O’Connell, C. \& Pellino, G,. (1980). Project for faculty development program; Final report. Ann Arbor, MI: Center for the Study of Higher Education, University of Michigan.

Bloom, A.D. (1987). Closing of the American mind. New York: Simon \& Schuster.

Bowen, H.R. \& Schuster, J.H. (1986). American professors: A national resource imperiled. New York: Oxford University.

Bowsher, J.E. (1989). Educating America: Lessons learned in the nation's corporations. New York: Wiley.

Boyer, E. (1990). Scholarship reconsidered: Priorities of the professoriate. Princeton, NJ: Carnegie Foundation for the Advancement of Teaching.

Carnegie Foundation for the Advancement of Teaching (1989). The condition of the professoriate: Attitude and trends._Princeton, NJ: Princeton University.

Cashin, W.E. (1988). Student ratings of teaching: A summary of the research. IDEA Paper No. 20. Manhatten, KS: Kansas State University. Center for Faculty Evaluation and Development.

Cashin, W.E. (1995). Student ratings of teaching: The research revisited. IDEA Paper No. 32. Manhatten, KS: Kansas State University. Center for Faculty Evaluation and Development.

Centra, J.A. (1976). Faculty development practices in U.S. colleges and universities. Princeton, NJ: Educational Testing Service.

Centra, J.A. (1993). Reflective teacher evaluation: Enhancing teaching and determining faculty effectiveness. San Francisco: Jossey-Bass.

Cervero, R.M. (1988). Effective continuing education for professionals. San Francisco: Jossey-Bass.

Chickering, A.W. \& Associates (1981). The modern American college: Responding to the new realities of diverse students and a changing society. San Francisco: Jossey-Bass. 
Chickering, A.W. \& Gamson, Z.F. (Eds.). (1991). Applying the seven principles of good practice in undergraduate education. New Directions for Teaching and Learning. No. 47. San Francisco: Jossey-Bass.

Chronicle of Higher Education (Feb. 7, 1990). New US Survey Assembles a Statistical Portrait of the American Professor, pp. A15-A18.

Cochran, L.H. (1989). Administrative commitment to teaching. Cape Giradeau, MO: Step Up Inc.

Cohen, P. A. (1990). Bring research into practice. In M. Theall \& J. Franklin (Eds.). Student ratings of instruction: Issues for improving practice. New Directions for Teaching and Learning. No. 43 (pp. 123-132). San Francisco: Jossey-Bass.

Cross, K.P. (1977). Not can, but will college teaching be improved? In Centra, J. (ed.) Renewing and evaluating teaching. New Directions for Higher Education, No. 17, pps. 1-15. San Francisco: Jossey-Bass.

Cross, K.P. (1990). Teachers as scholars. American Association for Higher Education Bulletin, 43(4) 3-5.

Cross, K.P. \& Angelo, T.A. (1988). Classroom assessment techniques: A handbook for faculty. Ann Arbor, MI: National Center for Research to Improve Postsecondary Teaching and Learning.

Dick, W. \& Carey, L. (1990). The systematic design of instruction (3rd ed.) Glenview, IL: Scott Foresman/Little Brown Higher Education.

Donald, J.G. (1986). An inventory of programs, courses and other kinds of pedagogical training of Higher Education personnel in Canada: A report to the European Centre for Higher Education. Montreal: Centre for Learning and Development, McGill University.

Donald, J.G. \& Shore, B.M. (1976). Annotated index to pedagogical services in Canadian colleges and universities. Montreal: Centre for Learning and Development, McGill University.

Eble, K.E. (1971). Career development of the effective college teacher. Washington, DC: American Association of University Professors.

Eble, K.E. \& McKeachie, W.J. (1985). Improving undergraduate education through faculty development._San Francisco: Jossey-Bass.

Erickson, G.R. (1992). Program descriptions: A collection of brief descriptions of faculty, instructional and organizational development programs in higher education. POD Network in Higher Education.

Feldman, K.A. (1987). Research productivity and scholarly accomplishment of college teachers as related to their instructional effectiveness: $A$ review and exploration. Research in Higher Education, 26, 227-298.

Feldman, K. A. (1989). Instructional effectiveness of college teachers as judged by teachers themselves, current and former students, colleagues, administrators, and external (neutral) observers. Research in Higher Education, 30, 137-194.

Freedman, M. (1979). Academic culture and faculty development. Berkeley, CA: Montaigne. 
Gaff, J.G. (1975). Toward faculty renewal. San Francisco: Jossey-Bass.

Geis, G.L. (1979). Instructional improvement and the concept of responsibility, or, Who's in charge here? Improving Human Performance Quarterly, 8(2) 70-79.

Geis, G.L. (1996). Planning and developing effective courses. In Menges, R. J. \& Weimer, M. (Eds.), Teaching on solid ground: Using scholarship to improve practice. San Francisco: Jossey-Bass.

Geis, G.L. \& Smith, R.A. (1977/78). What is a professor? Learning and Development 9 (3). Montreal: Centre for Learning and Development, McGill University.

Geis, G.L. \& Smith, R.A. (1989). If professors are adults... Journal of Staff, Program and Organization Development, 7(4) 155-163.

Grimmett, P.P. \& Erickson, G. (Eds.). (1988). Reflection in teacher education. New York: Teachers College Press.

Glazer, J. (1993). A teaching doctorate? The Doctor of Arts degree, then and now. Washington, DC: AAHE.

Gmelch, W.H., Lovrich, N.P., \& Wilke, P.K. (1984). Sources of stress in academe: A national perspective. Research in Higher Education, 20(4),477-490.

Gray, P.J., Froh, R.C. \& Diamond, R.M. (1992). A national study of research universities on the balance between research and undergraduate teaching. Syracuse, NY: Center for Instructional Development, Syracuse University.

Guba, E.G. \& Lincoln, Y.S. (1989). Fourth generation evaluation. Newbury Park, CA: Sage.

Houle, C.O. (1980). Continuing learning in the professions. San Francisco: Jossey-Bass.

Hruska, E.K. (1976). A study of role perceptions of faculty at the University of Massachusetts/Amherst. Dissertation Abstracts International, 36/09, 5864A. (University Microfilms No. 76-5344)

Konrad, A.G. (1983). Faculty development practices in Canadian Universities. The Canadian Journal of Higher Education, XIII, (2), 13-25.

Konrad, A.G. (1985). Faculty development in Canadian colleges. In C. Watson, (Ed.) The Professoriate - Occupation in Crisis. Toronto: The Higher Education Group, The Ontario Institute for Studies in Education.

Lindquist, J. (Ed.). (1978). Designing teaching improvement programs. Berkeley, CA: Pacific Soundings Press.

Mann, R.D. (1970). The college classroom: Conflict, change and learning. New York: John Wiley \& Sons.

Many, W.A., Ellis, J.R., \& Abrams, P. (1969). In-service education in American senior college and universities: A status report. DeKalb, IL: College of Education, Northern Illinois University.

Marincovich, M. (Ed.). (1996). Disciplinary differences in higher education. New Directions for Teaching and Learning, vol, 64. San Francisco: Jossey-Bass.

Martin, W.B. (Ed.). (1981). New perspectives on teaching and learning. New Directions for Teaching and Learning, vol, 7. San Francisco: Jossey-Bass. 
Mortimer, K.P., et al. (1984). Involvement in learning: Realizing the Potential of American Higher Education. National Institute of Education. Washington, DC: U.S. Government Printing Office.

Nelson, W.C. (1980). Faculty development: perceived needs for the 1980's. In W.C. Nelson, \& M.E. Siegel (Eds.), Effective approaches to faculty development. Washington, DC: Association of American Colleges.

Noonan, J.F. (Ed.). (1980). Learning about teaching. New Directions for Teaching and Learning, No. 4. San Francisco: Jossey-Bass.

Newell, A. \& Simon, H. (1972). Human problem solving. Englewood Cliffs, NJ: PrenticeHall.

North, J.D., (1995, October) "Read my lips": The academic administrator's role in the campus focus on teaching. AAHE Bulletin, 48(2), 3-6.

O'Connell, C. (1980). The influence of organizational policies and arrangements of faculty development programs upon faculty participation and changed teaching behavior. Dissertation Abstracts International 40/10, 5276A (University Microfilms No. 8007796).

Pellino, G.R., Boberg, A.L., Blackburn, R.T., \& O’Connell, C. (1981). Planning and evaluating professional growth programs for faculty. Ann Arbor, MI: Center for the Study of Higher Education, School of Education, University of Michigan.

Putman, R.W. (1990). Putting concepts to use: Re-educating professionals for organizational learning. Ed.D. thesis. Cambridge, MA: Harvard University, School of Education.

Rice, R.E. (1984). Being professional academically. In L. Buhl \& L. Wilson (Eds.), To Improve the Academy, 3, 5-13.

Richlin, L. (1995). Preparing the faculty of the future to teach. In W. A. Wright and Associates. Teaching improvement practices: Successful strategies for higher education (pp. 255-282). Bolton, MA: Anker.

Schön, D.A. (1983). The reflective practitioner: How professionals think in action. New York: Basic Books.

Schön, D.A. (1987). Educating the reflective practitioner: Toward a new design for teaching and learning in the professions. San Francisco: Jossey-Bass.

Seldin, P. (Ed.). (1987). Coping with faculty stress. New Directions for Teaching and Learning, 29. San Francisco: Jossey Bass.

Shulman, L. (1993a, January). Displaying teaching to a community of peers. Plenary address at AAHE Forum on Faculty Roles and Rewards, New Orleans.

Shulman, L. (1993b, November/December). Teaching as community property: Beyond pedagogical solitude. Change, 6,7 .

Shulman, L. (1996, January). Course anatomy: the dissection \& transformation of knowledge. Plenary address at AAHE Forum on Faculty Roles and Rewards, Atlanta, GA.

Smith, R.A . (1983). A theory of action perspective on faculty development. In M. Davis (Ed.), To improve the academy, 2, 47-58. 
Smith, R.A. (1984). Faculty perceptions of teaching improvement. Unpublished doctoral dissertation. Montreal: McGill University.

Smith, R.A. (1985). An application of Cross' Chain of Response model. Proceedings, CASAE conference. Montreal.

Smith, R.A. (1995). Reflecting critically on our efforts to improve teaching and learning. In E. Neal (Ed.), To improve the academy, 14, 5-25.

Smith, R.A. \& Schwartz, F, (1985). A theory of effectiveness: faculty development case studies. In J. Jeffrey \& G. Erickson (Eds.), To improve the academy, 4, 63-74.

Smith, S.L. (1991). Report of the Commission of Inquiry on Canadian University Education. Ottawa: Association of Universities and Colleges of Canada.

Sullivan, W.M. (1995). Work and integrity: The crisis and promise of professionalism in America. New York: Harper Collins.

Sykes, C.J. (1988). Profscam: Professors and the demise of higher education. Washington, DC: Regnery Gateway.

Task Force on Resource Allocation. (1994). Undergraduate teaching, research and consulting/community service: What are the functional connections? A literature survey. Toronto, ON: Ontario Council on University Affairs.

Taylor, K.L. (1993). The role of scholarship in university teaching. The Canadian Journal of Higher Education, XXIII-3, 64-79.

Terenzini, P.T. \& Pascarella, E.T. (1994 January/February). Living with myths: Undergraduate education in America. Change, 28-32.

Weimer, M., \& Lenze, L. F. (1991). Instructional interventions: A review of the literature on efforts to improve instruction. In J. Smart (Ed.), Higher education: Handbook of theory and research, 7, pp. 294-333.

Wright, W.A. \& O'Neill, M.C. (1995). Teaching improvement practices: International perspectives. In W.A. Wright and Associates. Teaching improvement practices: Successful strategies for higher education (pp. 1-57). Bolton, MA: Anker.

University of Manitoba Teaching Service. (1980). Survey of provision for academic staff development, United Kingdom and Canada. Mimeograph.

Wergin, J.F. (1994). The collaborative department: How five campuses are inching toward cultures of collaboration. Washington, DC: AAHE.

Wilkerson, L. (1977). University teaching: a study of faculty attitudes. Doctoral dissertation. Amherst, MA: University of Massachusetts.

Wilshire, B. (1989). The moral collapse of the university: Professionalism, purity and alienation. Albany, NY: State University of New York.

Wilson, R. \& Gaff, J.G. (1971). Faculty values and improving teaching. In G.K. Smith (Ed.), New Teaching, new learning. San Francisco: Jossey-Bass. 


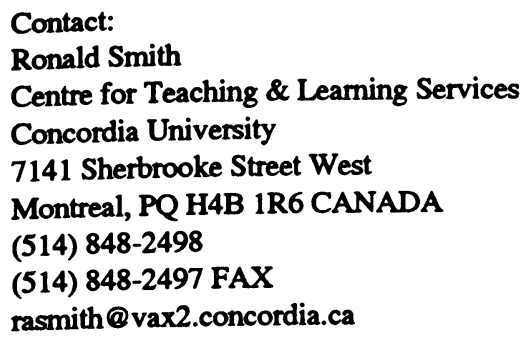

Ron Smith is professor of Adult Education and the Director of the Centre for Teaching and Learning Services at Concordia University in Montreal. His current interests are in the professionalization of professional development and in the application of the concept of "reflective practice" to improve teaching in higher education.

George Geis is professor of Higher Education at the Ontario Institute for Studies in Education - University of Toronto. He has long been involved in faculty development, first at the University of Michigan and later at McGill University where he was the Director of the Centre for University Teaching and Leaming. His current interests are in the area of course planning and revision. 